\title{
Seismic Evaluation of RC Framed Building With and Without Shear Walls (Performance Based Design
}

\author{
J. Muralidhara Rao ${ }^{1}$, Dr. K. Rajasekhar ${ }^{2}$ \\ ${ }^{1}$ PG Student, Department of Civil Engineering, Siddartha Educational Academy Group of Institutions/Integrated Campus, Tirupati (Rural)/ \\ , Affiliated to /JNTUA Ananthapuramu, (India)
}

${ }^{2}$ Professor, Department of Civil Engineering, Siddartha Educational Academy Group of Institutions/Integrated Campus, Tirupati (Rural), Affiliated to /JNTUA Ananthapuramu, (India)

\begin{abstract}
About 60\% of Indian land is in zone III,IV and V. Major cities like Mumbai, Chennai, Delhi etc are in seismic prone zones. Buildings in these cities are vulnerable to earthquakes and most of the old buildings in these areas are designed and constructed without considering seismic effect. So evaluating the performance and strengthening of these structures, if necessary is essential. There are linear static methods namely code compliance method and nonlinear static methods which are also called as pushover methods namely capacity spectrum method and displacement coefficient method are available. Procedure for evaluating the structures using these methods were studied in this work and a case study on a structure were done using above methods.
\end{abstract}

Keywords: MDOF multi degree of freedom, SDOF single degree of freedom

\section{Introduction}

Pushover analysis is mainly to evaluate existing buildings and retrofit them. It can also be applied for new structures. $\mathrm{RC}$ framed buildings would become massive if they were to be designed to behave elastically during earthquakes without damage, also they become uneconomical. Therefore, the structures must undergo damage to dissipate seismic energy. To design such a structure, it is necessary to know its performance and collapse pattern. To know the performance and collapse pattern, nonlinear static procedures are helpful.

Nonlinear static analysis, or pushover analysis has been developed over the past twenty years and has become the preferred analysis procedure for design and seismic performance evaluation purposes as the procedure is relatively simple and considers post-elastic behaviour. However, the procedure involves certain approximations and simplifications that some amount of variation is always expected to exist in seismic demand prediction of pushover analysis.

\section{Literature Review on Pushover Analysis}

\subsection{Past studies on pushover analysis}

Most of the simplified nonlinear analysis procedures utilized for seismic performance evaluation make use of pushover analysis and/or equivalent SDOF representation of actual structure. However, pushover analysis involves certain approximations that the reliability and the accuracy of the procedure should be identified. For this purpose, researchers investigated various aspects of pushover analysis to identify the limitations and weaknesses of the procedure and proposed improved pushover procedures that consider the effects of lateral load patterns, higher modes, failure mechanisms, etc. Krawinkler and Seneviratna conducted a detailed study that discusses the advantages, disadvantages and the applicability of pushover analysis by considering various aspects of the procedure. The basic concepts and main assumptions on which the pushover analysis is based, target displacement estimation of MDOF structure through equivalent

SDOF domain and the applied modification factors, importance of lateral load pattern on pushover predictions, the conditions under which pushover predictions are adequate or not and the information obtained from pushover analysis were identified. The accuracy of pushover predictions was evaluated on a 4-story steel perimeter frame damaged in 1994 Northridge earthquake. The frame was subjected to nine ground motion records. Local and global seismic demands were calculated from pushover analysis results at the target displacement associated with the individual records. The comparison of pushover and nonlinear dynamic analysis results showed that pushover analysis provides good predictions of seismic demands for low-rise structures having uniform distribution of inelastic behaviour over the height. It was also recommended to implement pushover analysis with caution and judgment considering its many limitations since the method is approximate in nature and it contains many unresolved issues that need to be investigated.

\subsection{Description of Pushover Analysis}

The pushover analysis of a structure is a static non-linear analysis under permanent vertical loads and gradually increasing lateral loads. The equivalent static lateral loads approximately represent earthquake induced forces. A plot of the total base shear versus top displacement in a structure is obtained by this analysis that would indicate any premature failure or weakness. The analysis is carried out up to failure, 


\section{International Journal of Science and Research (IJSR) \\ ISSN (Online): 2319-7064}

Index Copernicus Value (2013): 6.14 | Impact Factor (2015): 6.391

thus it enables determination of collapse load and ductility capacity. On a building frame, and plastic rotation is monitored, and lateral inelastic forces versus displacement response for the complete structure is analytically computed. This type of analysis enables weakness in the structure to be identified. The decision to retrofit can be taken in such studies.

The seismic design can be viewed as a two step process. The first, and usually most important one, is the conception of an effective structural system that needs to be configured with due regard to all important seismic performance objectives, ranging from serviceability considerations. This step comprises the art of seismic engineering. The rules of thumb for the strength and stiffness targets, based on fundamental knowledge of ground motion and elastic and inelastic dynamic response characteristics, should suffice to configure and rough-size an effective structural system.

Elaborate mathematical/physical models can only be built once a structural system has been created. Such models are needed to evaluate seismic performance of an existing system and to modify component behavior characteristics (strength, stiffness, deformation capacity) to better suit the specified performance criteria.

The second step consists of the design process that involves demand/capacity evaluation at all important capacity parameters, as well as the prediction of demands imposed by ground motions. Suitable capacity parameters and their acceptable values, as well as suitable methods for demand prediction will depend on the performance level to be evaluated.

However, Pushover analysis consists of a series of sequential elastic analyses, superimposed to approximate a forcedisplacement curve of the overall structure. A two or three dimensional model which includes bilinear or tri-linear loaddeformation diagrams of all lateral force resisting elements is first created and gravity loads are applied initially. A predefined lateral load pattern which is distributed along the building height is then applied. The lateral forces are increased until some member's yield. The structural model is modified to account for the reduced stiffness of yielded members and lateral forces are again increased until additional member's yield. The process is continued until a control displacement at the top of building reaches a certain level of deformation or structure becomes unstable. The roof displacement is plotted with base shear to get the global capacity curve (Figure 1).

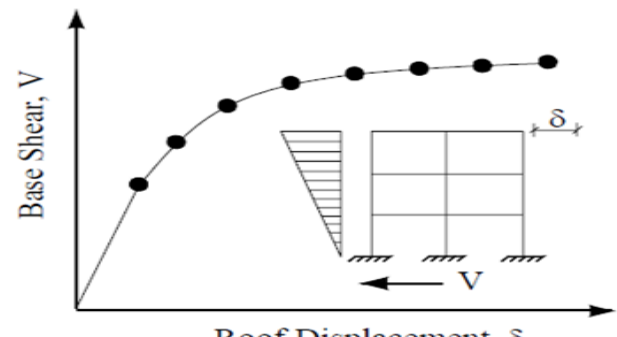

Figure 1: Global Capacity (pushover) of a structure

\subsection{Purpose of Non-linear Static Push-over Analysis}

The pushover is expected to provide information on many response characteristics that cannot be obtained from an elastic static or dynamic analysis. The following are the examples of such response characteristics:

- The realistic force demands on potentially brittle elements, such as axial force demands on columns, force demands on brace connections, moment demands on beam to column connections, shear force demands in deep reinforced concrete spandrel beams, shear force demands in unreinforced masonry wall piers, etc.

- Estimates of the deformations demands for elements that have to form in elastically in order to dissipate the energy imparted to the structure.

- Consequences of the strength deterioration of individual elements on behavior of structural system.

- Consequences of the strength deterioration of the individual elements on the behavior of the structural system.

- Identification of the critical regions in which the deformation demands are expected to be high and that have to become the focus through detailing.

- Identification of the strength discontinuities in plan elevation that will lead to changes in the dynamic characteristics in elastic range.

- Estimates of the inter storey drifts that account for strength or stiffness discontinuities and that may be used to control the damages and to evaluate P-Delta effects.

- Verification of the completeness and adequacy of load path, considering all the elements of the structural system, all the connections, the stiff nonstructural elements of significant strength, and the foundation system.

The last item is the most relevant one as the analytical model incorporates all elements, whether structural or nonstructural, that contribute significantly to the lateral load distribution. Load transfer through across the connections through the ductile elements can be checked with realistic forces; the effects of stiff partial-height infill walls on shear forces in columns can be evaluated; and the maximum overturning moment in walls, which is often limited by the uplift capacity of foundation elements can be estimated.

These benefits come at the cost of the additional analysis effort, associated with incorporating all important elements, modeling their inelastic load-deformation characteristics, and executing incremental inelastic analysis, preferably with three dimensional analytical models.

\subsection{Adaptability of computer programs}

It is well known fact the distribution of mass and rigidity is one of the major considerations in the seismic design of moderate to high rise buildings. Invariably these factors introduce coupling effects and non-linearity's in the system, hence it is imperative to use non-linear static analysis approach by using specialized programs viz., ETABS, STAADPRO2005, IDARC, NISA-CIVIL, etc., for costeffective seismic evaluation and retrofitting of buildings. 


\section{International Journal of Science and Research (IJSR) \\ ISSN (Online): 2319-7064}

Index Copernicus Value (2013): 6.14 | Impact Factor (2015): 6.391

\subsection{Procedure to do pushover analysis}

Nonlinear static pushover analysis is a very powerful feature offered in the Nonlinear version of ETABS. Pushover analysis can be performed on both two and three dimensional structural models. A pushover case may start from zero initial conditions, or it may start from the end of a previous pushover case. However, ETABS allows plastic hinging during "Gravity" pushover analysis. ETABS can also perform pushover analysis as either force-controlled or displacement-controlled.

1) Create the basic computer model (without the pushover data) in the usual manual. The graphical interface of ETABS makes this a quick and easy task.

2)Define hinge properties and acceptance criteria for the pushover hinges using moment rotation relations as shown in next topic. The program includes several built-in default hinge properties that are based on average values from ATC-40 for concrete members and average values from FEMA-273 for steel members. These built in properties can be useful for preliminary analyses, but user-defined properties are recommended for final analyses. This example uses default properties.

3)Locate the pushover hinges on the model by selecting one or more frame members and assigning them one or more hinge properties and hinge locations.

4)Define the pushover load cases. In ETABS more than one pushover load case can be run in the same analysis. Also a pushover load case can start from the final conditions of another pushover load case that was previously run in the same analysis. Typically, the first pushover load case is used to apply gravity load and then subsequent lateral pushover load cases are specified to start from the final conditions of the gravity pushover. Pushover load cases can be force controlled, that is, pushed to a certain defined force level, or they can be displacement controlled, that is, pushed to a specified displacement. Typically, a gravity load pushover is force controlled and lateral pushovers are displacement controlled. ETABS allows the distribution of lateral force used in the pushover to be based on a uniform acceleration in a specified direction, a specified mode shape, or a user-defined static load case.

\subsubsection{User defined Hinge properties}

In pushover analysis, it is necessary to model the non-linear load-deformation behavior of the elements. Beams and columns should have moment versus rotation and shear force versus shear deformation hinges. For columns, the rotation of the moment hinge can be calculated for the axial load available from the gravity load analysis. All compression struts have to be modeled with axial load versus axial deformation hinges.

An idealized load-deformation curve is shown in figure below. It is a piece-wise linear curve defined by five points as explained below.

(i)Point ' $A$ ' corresponds to the unloaded condition.

(ii)Point ' $\mathrm{B}$ ' corresponds to the onset of yielding.

(iii)Point ' $C$ ' corresponds to the ultimate strength.

(iv)Point ' $\mathrm{D}$ ' corresponds to the residual strength. For the computational stability, it is recommended to specify nonzero residual strength. In absence of the modeling of the descending branch of a load-deformation curve, the residual strength can be assumed to be $20 \%$ of the yield strength.

(v) Point ' $E$ ' corresponds to the maximum deformation capacity with the residual strength.

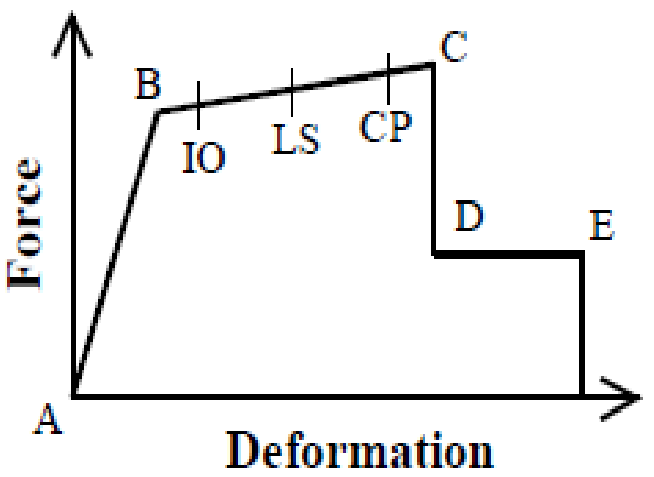

Figure 2: General Hinge property

\subsubsection{Moment-Curvature relations:}

Moment curvature is representation of behaviour of the member. The moment curvature relationship is established using following procedure for a structural element.

\subsubsection{Material properties for moment curvature:}

Stress strain models used for evaluation of moment curvature relations are Kent and park concrete model and IS 456 steel stress strain model.

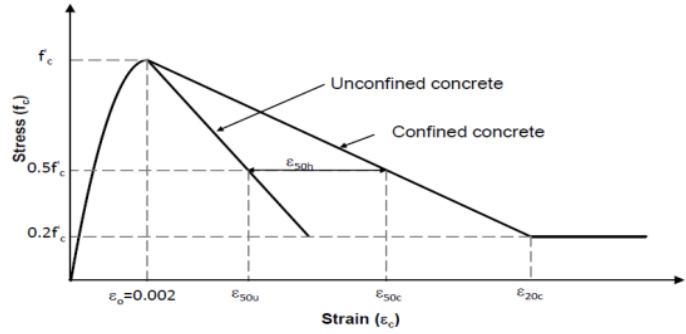

Figure 3: Kent and park concrete model

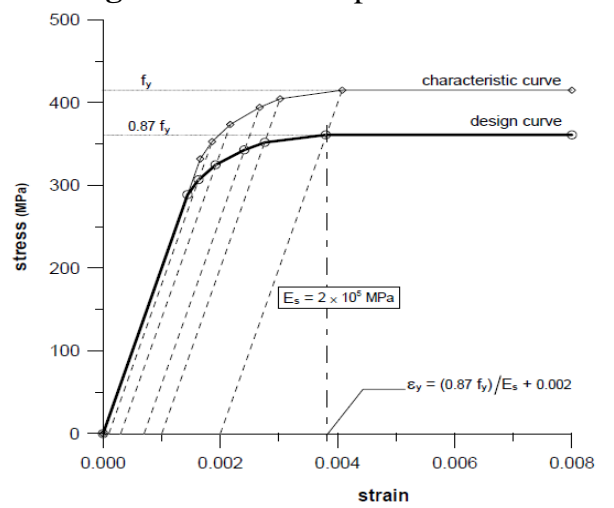

Figure 4: IS 456 stress strain curve for steel

\subsubsection{Procedure to determine moment curvature curve:}

1) Section is divided into elemental strip.

2) Select the extreme compressive fibre strain, $\epsilon_{\mathrm{cm}}$ and neutral axis depth $\mathrm{Kd}$.

3)The strain and stress at each strip level is calculated for varying neutral axis from strain profile and stress strain relationship i.e. $\epsilon \mathrm{si}=\epsilon \mathrm{cm}^{*}(\mathrm{kd}-\mathrm{di}) / \mathrm{kd}$. As shown in below stress block figure. 


\section{International Journal of Science and Research (IJSR) \\ ISSN (Online): 2319-7064 \\ Index Copernicus Value (2013): 6.14 | Impact Factor (2015): 6.391}

4) Determine forces in steel in compression and tension regions i.e. $\mathrm{C}_{\mathrm{s}}$ or $\mathrm{T}_{\mathrm{s}}=$ fsi*Asi

5) Calculate compressive force in concrete i.e. $\mathrm{C}_{\mathrm{con}}=$ $\alpha^{*} f c^{*}{ }^{*} * k d$.

6) $\alpha$ and $\Upsilon$ are rectangular stress block parameters.

7) They can be determined by concrete model in different zones.

$\alpha=\int \mathrm{fc} \mathrm{d} \mathrm{ecm}$ $\gamma=\int \epsilon \mathrm{c} \mathrm{fc} \mathrm{d} \epsilon \mathrm{cm}$

8) Now, actual kd can be determined by doing iterations using force equilibrium eqn.

9) $\mathrm{P}=\mathrm{Ccon}+\mathrm{Cs}-\mathrm{Ts}$

10) For beams it should be equal to zero and for columns it should be equal to axial force in the column.

11) By using actual $\mathrm{kd}$ and $\epsilon \mathrm{cm}, M$ and phi values can be determined as shown

12) $\mathrm{M}=(\mathrm{Ccon} * \mathrm{~L} . \mathrm{A})+(\mathrm{Cs} * \mathrm{~L} . \mathrm{A})+(\mathrm{Ts} * \mathrm{~L} . \mathrm{A})$ and $\varphi=$ $\epsilon_{\mathrm{cm}} / \mathrm{kd}$

13) Consider different $\epsilon \mathrm{cm}$ values till the ultimate strain $\left(\epsilon_{\mathrm{u}}\right)$ is reached and get a set of $\quad M$ and $\varphi$ values and develop a plot with $\mathrm{M}$ along $\mathrm{y}$-axis and $\varphi$ along $\mathrm{x}$-axis.

14) $\epsilon_{\mathrm{u}}=0.003+0.002(\mathrm{~b} / \mathrm{z})+0.2 . \rho_{\mathrm{s}}$

15) The moment and curvature is noted at this instance.

16) For each extreme compression strain varying from zero to ultimate strain, moment curvature relationship is established.

17) The moment curvature curves is converted into idealized bilinear curves



Figure 7: Stress blocks at different extreme compression fibre strain



Figure 5: Moment curvature curve

\section{Case Study}

\subsection{Structure Information}

A ground plus five storey RC building of plan dimensions $23 \mathrm{~m} \times 19 \mathrm{~m}$ and height of building is $18 \mathrm{~m}$ located in seismic zone II on hard soil is considered. It is assumed that there is no parking floor for this building. Seismic analysis is performed using the codal seismic coefficient method. Since the structure is a regular building with a height less than $16.50 \mathrm{~m}$, as per Clause 7.8.1 of IS 1893 (Part 1): 2002, a dynamic analysis need not be carried out. The effect of finite size of joint width (e.g., rigid offsets at member ends) is not considered in the analysis. However, the effect of shear deformation is considered. Detailed design of the beams along longitudinal and transverse as per recommendations of IS 13920:1993 has been carried out.

\subsection{Geometry of the structure:}

\begin{tabular}{|l|l|l|l|l|}
\hline \multicolumn{1}{|c|}{$4.5 \mathrm{~m}$} & $4.5 \mathrm{~m}$ & $5 \mathrm{~m}$ & $4.5 \mathrm{~m}$ & $4.5 \mathrm{~m}$ \\
\hline $3.5 \mathrm{~m}$ & & & & \\
\hline $4 \mathrm{~m}$ & & & & \\
\hline $3.5 \mathrm{~m}$ & & & & \\
\hline $4 \mathrm{~m}$ & & & & \\
\hline
\end{tabular}

Figure 6: Plan of the building

\section{Dimensions of the structural elements:}

Columns : $0.4 \times 0.4$

Beams : $0.3 \times 0.4$

Slab thickness $\quad: 0.12$

(All dimensions are in meters)

\subsection{Material properties and loads:}

For this study material property and loads has been used as follows

Grade of concrete: M20

Grade of steel: Fe 415

Live load on floors $=2 \mathrm{kN} / \mathrm{m}^{2}$

Density of concrete $=25 \mathrm{kN} / \mathrm{m}^{3}$

\subsection{Modelling in ETABS}

Beams and Columns were modelled with concentrated plastic hinges at the column and beam faces respectively. Beams have majorly bending moment $(\mathrm{M})$ and shear force $(\mathrm{V})$, whereas columns have axial load and bending moments in two directions ( $\mathrm{P}, \mathrm{M}_{2}$ and $\mathrm{M}$ ). The plastic hinge rotation and moment values corresponding to yield and ultimate states arrived at for each section and used to define the hinge properties as explained earlier. A brief description of the hinges is provided.

\subsubsection{Beams}

Beams are modelled as frame members as line elements with plastic hinges at both ends. Hinge properties were calculated as per reinforcement and cross section at ends.

\subsubsection{Columns}

Columns are also modelled as line element with plastic hinges at ends. In columns axial force and biaxial bending moments are considered and hinges are modelled as $\mathrm{P}-\mathrm{M}_{2}-\mathrm{M}_{3}$ 


\section{International Journal of Science and Research (IJSR) \\ ISSN (Online): 2319-7064}

Index Copernicus Value (2013): 6.14 | Impact Factor (2015): 6.391

\subsubsection{Slabs}

Slabs are modelled as area elements (shell). Live loads on slabs are given as uniform to frame shell.

\subsubsection{Footings}

Foundations are modelled as fixed footing no moments, deflections and sinking of supports were allowed.

\section{Analysis and Design}

\subsection{Gravity load analysis}

Dead loads of beams, columns, slabs and walls are calculated using member properties and unit weights. Live load of 2 $\mathrm{KN} / \mathrm{m}$ is applied on slabs. Bending moments and shear forces are calculated using gravity loads.

\subsection{Lateral load analysis}

Lateral loads due to earthquake are calculated using equivalent static analysis as explained in IS 1893.

\subsubsection{Equivalent static analysis:}

The total design lateral force or design seismic base shear $(\mathrm{V})$ is calculated according to clause 7.5.3 of IS 1893:2002 (IS $S^{\mathrm{B}} 1893: 2002$ is referred to as the Code subsequently).

The total Base shear is given by

$\boldsymbol{V}=\boldsymbol{H}_{\boldsymbol{a}} \boldsymbol{w k}$

Where $\mathrm{A}_{\mathrm{h}}$ is the design horizontal seismic coefficient

$$
A_{\mathrm{h}}=\frac{Z I S_{\mathrm{a}}}{2 R g}
$$

Here

$\mathrm{Z}=$ Zone Factor (as per zone II)

$\mathrm{I}=$ Importance Factor $(\mathrm{I}=1)$

$\mathrm{R}=$ Response Reduction Factor $(\mathrm{OMRF}=3)$

The values of Z, I, R are given in IS 1893 (part-1):2002.

$\mathrm{S} / \mathrm{g}=$ Spectral acceleration coefficient. It is calculated according to Clause 6.4 .5 of the Code corresponding to the fundamental time period $\mathrm{T}$ in seconds is given as follows.

For a Moment Resisting Frame without brick infill panels

Ta $=0.075 \boldsymbol{h}^{0.75}$ for RC frame building

Here

$\mathrm{h}=$ Height of the Building Frame

Base shear is then distributed to storey levels as storey shears $\mathrm{Qi}=(\mathrm{Ah}) * \frac{W i * h i}{\sum(W i * h i 2)}$

Here

$\mathrm{Qi}=$ Design lateral force at floor $\boldsymbol{I}$,

$\mathrm{Wi}=$ Seismic weight of floor I,

$\boldsymbol{h i}=$ Height of floor $\boldsymbol{I}$ measured from base, and

$\boldsymbol{n}=$ Number of storeys in the building is the number of levels at which the masses are located.

\subsubsection{Stiffness of the frame}

Stiffness of the frames is found out by giving unit force at top joint.

$$
\mathrm{F}=\mathrm{K} * \delta
$$

Depending on stiffness of frames storey level shears are distributed to each nodes as follows.

$$
\mathrm{F} 1=\mathrm{Q} 1 *\left(\frac{K 1}{K 1+K 2+K 3_{\ldots m}}\right)
$$

In the present case, center of mass and center of stiffness coincides each other and no torsional forces are developed. Hence lateral forces are applied at every floor levels.

\subsubsection{Application of lateral loads}

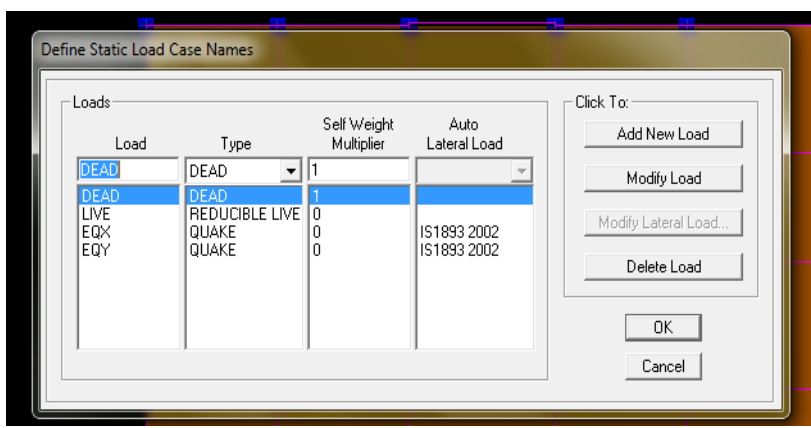

\subsubsection{Load Combinations}

Load combinations are considered as per IS 456: 2000 and are given in table $\mathrm{EQ}_{\mathrm{X}}$ implies earthquake loading in $\mathrm{X}$ direction and EQY stands for earthquake loading in $\mathrm{Y}$ direction. The emphasis here is on showing typical calculations for ductile design and detailing of building elements subjected to earthquakes. In practice, wind load should also be considered in lieu of earthquake load and the critical of the two load cases should be used for design. This analysis only three combinations were used as shown in Table.

Table 2: Load combinations for earthquake loading

\begin{tabular}{|c|c|c|c|c|}
\hline S. No & Load Combination & DL & LL & EQ \\
\hline 1 & $1.5 \mathrm{DL}+1.5 \mathrm{LL}$ & 1.5 & 1.5 & - \\
\hline 2 & $1.2\left(\mathrm{DL}+\mathrm{LL}^{*}+\mathrm{EQX}\right)$ & 1.2 & $0.25 / 0.5^{*}$ & +1.2 \\
\hline 3 & $1.2\left(\mathrm{DL}+\mathrm{LL}^{*}\right.$-EQX) & 1.2 & $0.25 / 0.5^{*}$ & -1.2 \\
\hline 4 & $1.2\left(\mathrm{DL}+\mathrm{LL}^{*}+\mathrm{EQY}\right)$ & 1.2 & $0.25 / 0.5^{*}$ & +1.2 \\
\hline 5 & $1.2\left(\mathrm{DL}+\mathrm{LL}^{*}\right.$-EQY) & 1.2 & $0.25 / 0.5^{*}$ & -1.2 \\
\hline 6 & $1.5(\mathrm{DL}+\mathrm{EQX})$ & 1.5 & - & +1.5 \\
\hline 7 & $1.5(\mathrm{DL}-\mathrm{EQX})$ & 1.5 & - & -1.5 \\
\hline 8 & $1.5(\mathrm{DL}+\mathrm{EQY})$ & 1.5 & - & 1.5 \\
\hline 9 & $1.5(\mathrm{DL}-\mathrm{EQY})$ & 1.5 & - & -1.5 \\
\hline 10 & $0.9 \mathrm{DL}+1.5 \mathrm{EQX}$ & 0.9 & - & +1.5 \\
\hline 11 & $0.9 \mathrm{DL}-1.5 \mathrm{EQX}$ & 0.9 & - & -1.5 \\
\hline 12 & $0.9 \mathrm{DL}+1.5 \mathrm{EQY}$ & 0.9 & - & +1.5 \\
\hline 13 & $0.9 \mathrm{DL}-1.5 \mathrm{EQY}$ & 0.9 & - & -1.5 \\
\hline
\end{tabular}

*Note: Reduced Live loads are considered as per Clause 7.3.1 of IS 1893 (Part 1).

\subsection{Design of frame members}

Worst cases are considered and bending moments, shear forces and axial forces from these cases are taken for design. The design of all beam and column based on IS: 456 and IS 13920. Due to symmetry of plan, selected as X-direction and beam and column members were designed and checking were 


\section{International Journal of Science and Research (IJSR) \\ ISSN (Online): 2319-7064}

Index Copernicus Value (2013): 6.14 | Impact Factor (2015): 6.391

done all requirement both IS: 456 and IS 13920. The longitudinal and transverse reinforcement with spacing for both beam and column are as shown.

\subsubsection{IS 456 Detailing}

As per is $456: 2000$, the design of the structural members is to be carried out by ordinary detailing by providing corresponding development lengths of the bar diameters after curtailment of the bar. By this, a weak section is formed at the curtailment zone. So, in earthquake prone zones, ductile detailing is preferred also for important structures.

\subsubsection{IS: 13920 ductile design details:}

The top as well as bottom reinforcement shall consist of at least two bars throughout the member length. This makes the member more ductile and resists the loads. Some of the rules to be followed as per IS13920 for beam and column detailing are as shown below.

In an external joint, both the top and the bottom bars of the beam shall be provided with anchorage length, beyond the inner face of the column, equal to the development length intension plus 10 times the bar diameter minus the allowance for 90-degree bend(s) (see Fig) In an internal joint, both face bars of the beam shall be taken continuously through the column.

\subsubsection{Ductile Detailing of Beam}

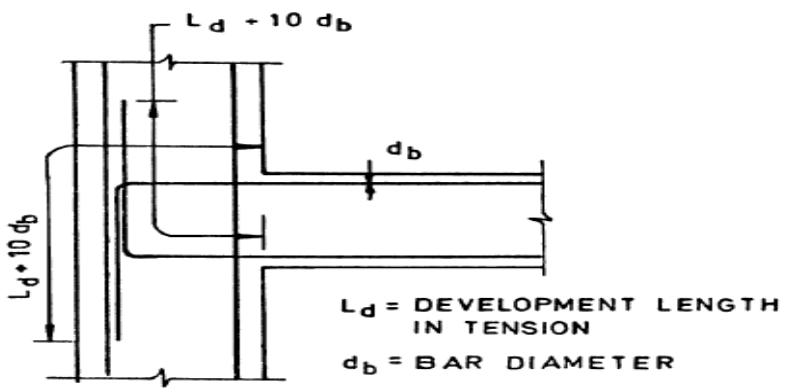

Figure 7: Anchorage Of Beam Bars In An External Joint

The longitudinal bars shall be spliced, only if hoops are provided over the entire splice length, at a spacing not exceeding $150 \mathrm{~mm}$ (see Fig) The lap length shall not be less than the bar development length in tension. Lap splices shall not be provided

a) within a joint,

b) within a distance of $2 d$ from joint face, and

c) within a quarter length of the member where flexural yielding may generally occur under the effect of earthquake forces. Not more than 50 percent of the bars shall be spliced at one section.

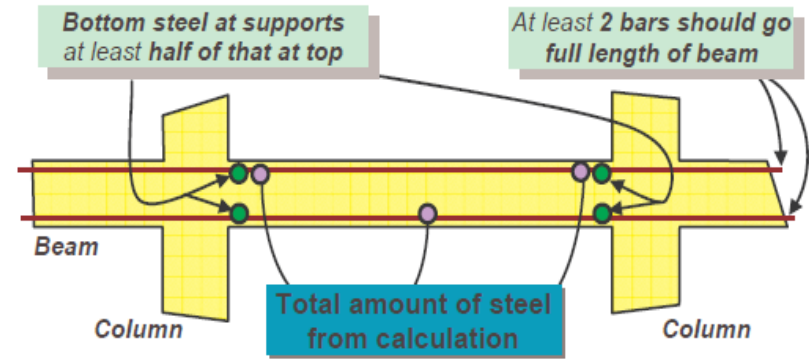

Figure 8: longitudinal reinforcement for ductile detailing

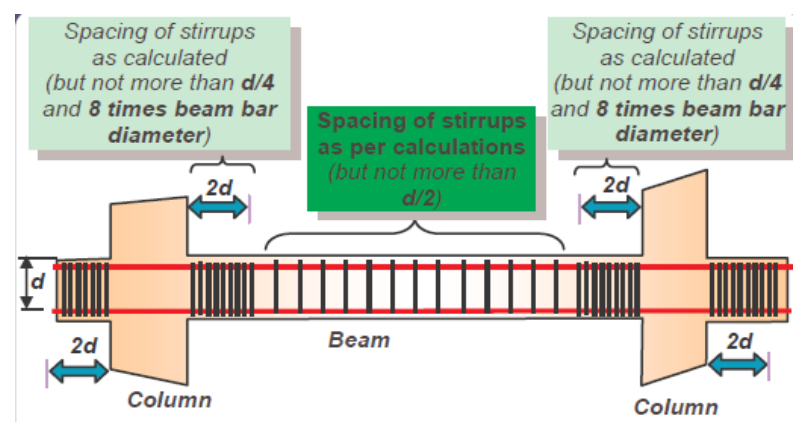

Figure 9: shear reinforcement for ductile detailing

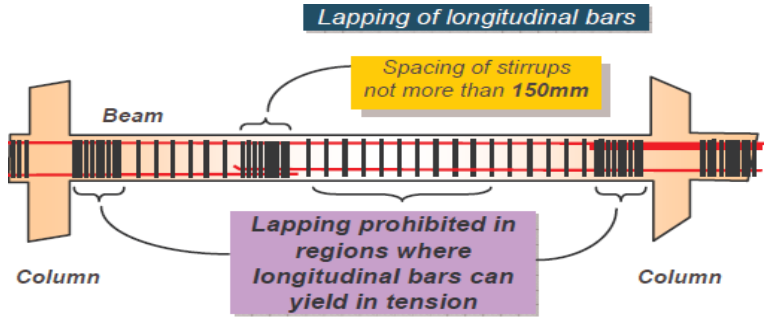

Figure 10: Lapping for shear reinforcement for ductile detailing

\subsection{Performance of building with shear walls}

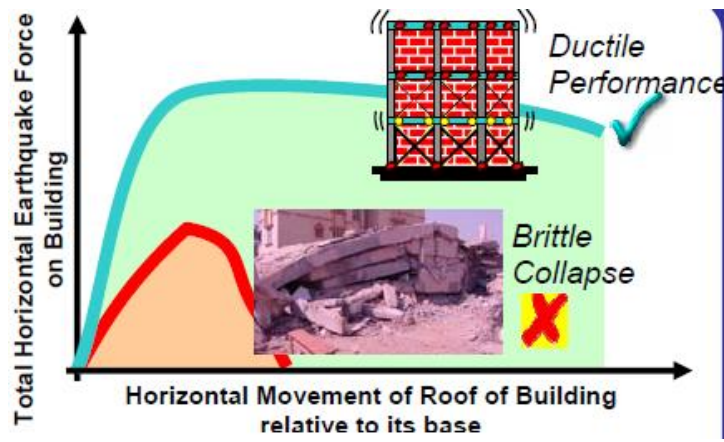

Figure 11: Ductile Performance of Building

\section{Seismic evaluation of building}

\subsection{ETabs model}

A structure with 5 bay- 5 bay six storied is modelled with parameters explained in above chapters.

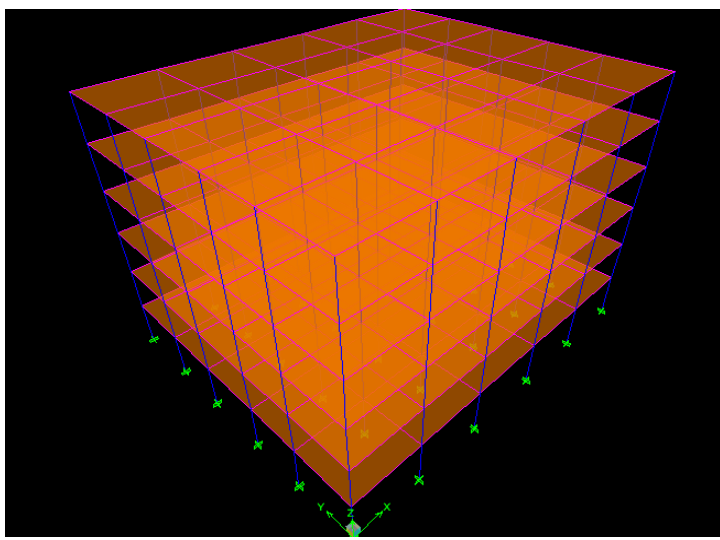

Figure 12: Structure model in ETabs

\section{Volume 5 Issue 6, June 2016 www.ijsr.net}




\section{International Journal of Science and Research (IJSR) \\ ISSN (Online): 2319-7064}

Index Copernicus Value (2013): 6.14 | Impact Factor (2015): 6.391

\subsubsection{Moment curvature}

Having all the design details, moment curvatures for all beams and columns at end cross sections where plastic hinges are assumed to form are determined. This is done by preparing an excel spread sheet. Moment curvature curves for different beams and columns of the structure are shown below.

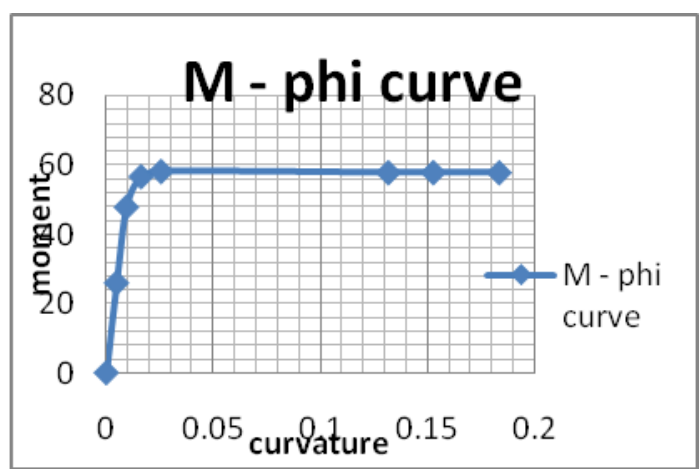

Figure 13: Moment curvature curves for beams with nonductile detailing

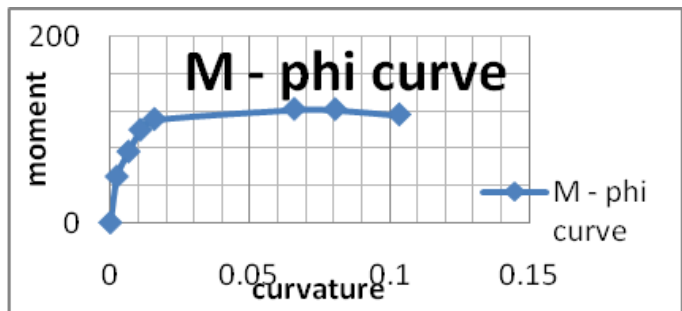

Figure 14: Moment curvature curves for columns with nonductile detailing

\subsubsection{Moment rotation relations and hinge properties:} Obtaining yield and ultimate moments and curvatures from moment curvature curves, moment rotations are derived as explained in earlier chapter.

From moment rotation relations, hinge properties are assumed as shown below figure with acceptance criteria as shown and assigned in ETABS.

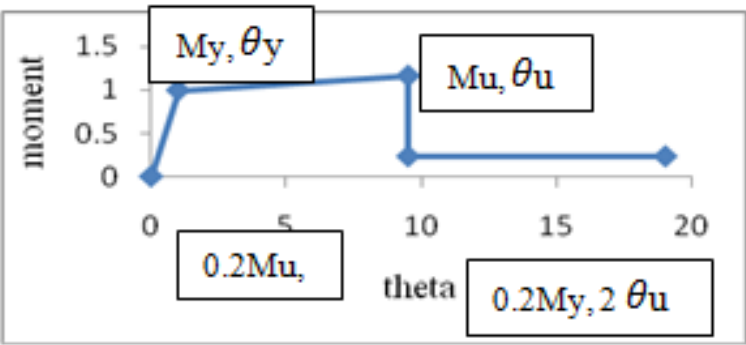

Figure 15: Assumed hinge model

\subsubsection{Acceptance criteria:}

Member performance levels are assumed as follows

Figure 16: Acceptance criteria of hinges

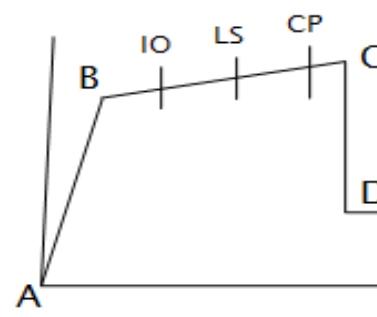

Immediate occupancy IO $=0.67 * \mathrm{LS}$

Life safety LS $=0.75 *$ deformation @ point C

Collapse prevention $\mathrm{CP}=$ deformation @ point $\mathrm{C}$ but not > 0.75*deformation@E

\subsubsection{Pushover analysis in ETabs:}

Design is carried out as per IS 456-2000 than select all beam to assign hinge properties from Assign > Frame/Line >

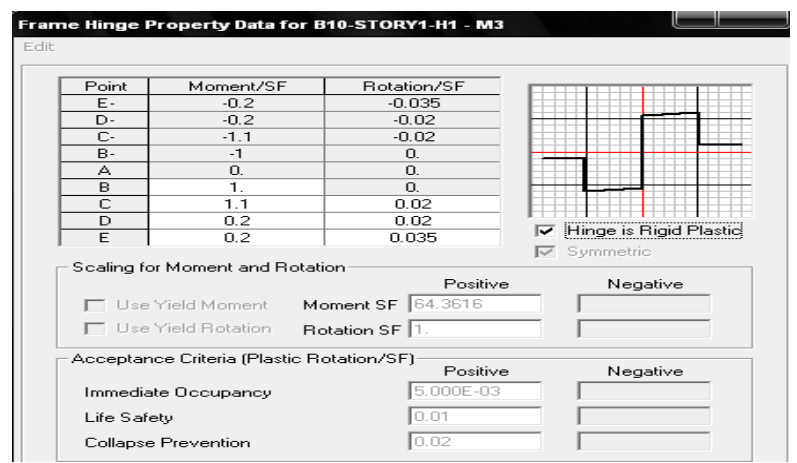

Figure 17: Frame hinge property for beam in ETabs

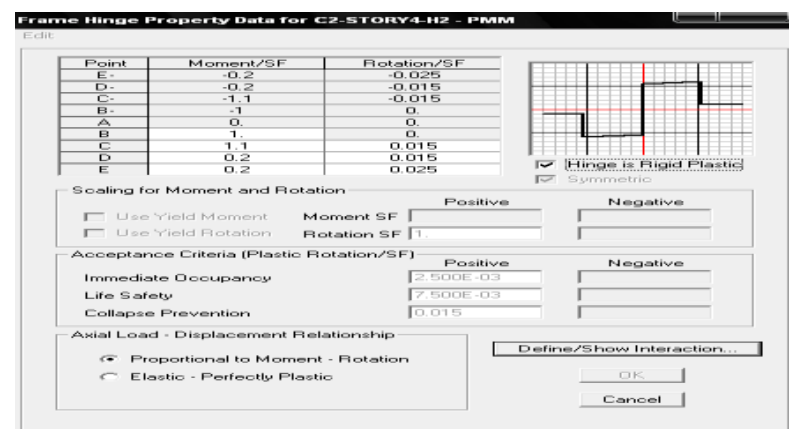

Figure 18: Frame hinge property for column in ETabs

Defining static nonlinear load cases from Define > Static Nonlinear/Pushover command.

For push over analysis first apply the gravity loading as PUSHDOWN shown in Figure and subsequently use lateral displacement or lateral force as PUSH 2 in sequence to derive capacity curve and demand curve as shown in Figure. Start from previous pushover case as PUSHDOWN for gravity loads is considered for lateral loading as PUSH 2.

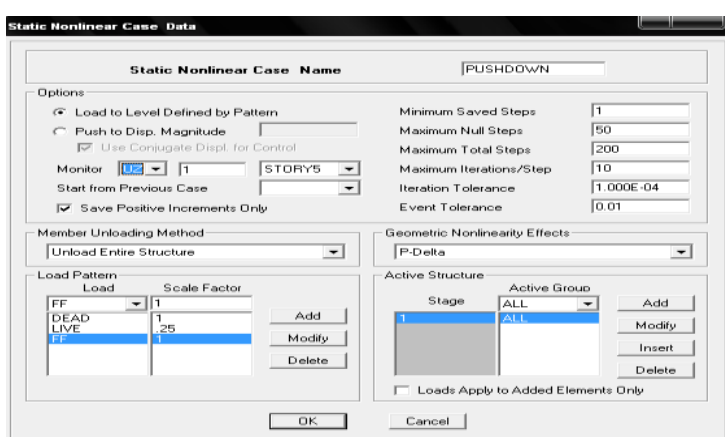

Figure 19: Assigning pushover case for dead load

\section{ne 5 Issue 6, June 2016 www.ijsr.net}




\section{International Journal of Science and Research (IJSR) \\ ISSN (Online): 2319-7064}

Index Copernicus Value (2013): 6.14 | Impact Factor (2015): 6.391

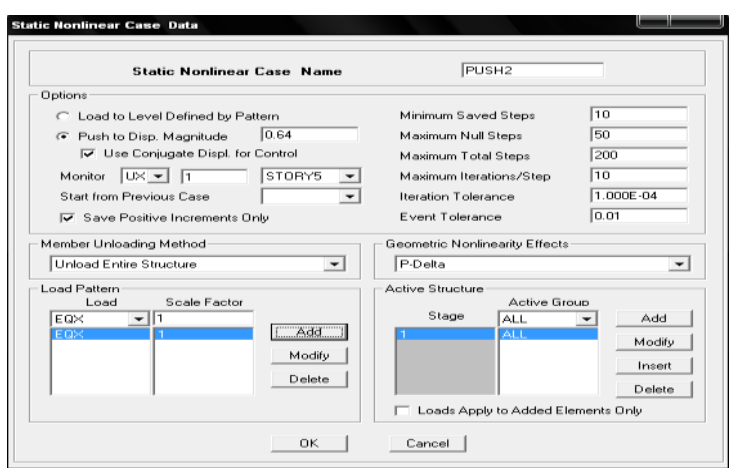

Figure 20: Assigning pushover case for lateral load

\subsubsection{ETab model with shear wall:}

at the centre bays along the outer periphery

Wall thickness: $230 \mathrm{~mm}$

Wall property assigned in ETabs: shell

Wall is designed as per ordinary moment resisting frame and special moment resisting frame with respect to response reduction factor " $\mathrm{R}$ " factor given in ETabs.

For OMRF, $\mathrm{R}=3$

For $\mathrm{SMRF}, \mathrm{R}=5$



Figure 21: Model of the building with shear wall

\subsection{Nonlinear hinge property calculation}

Nonlinear hinge properties, as assigned in SAP2000 model, were calculated as described in the following.

Shear wall PMM hinge: For any given shear wall, PMM hinge property was calculated in the following two steps:

5.3.1PMM interaction surface: $P M M$ interaction surface determines the load at which a shear wall section becomes inelastic and forms a hinge. For a given wall section geometry, material and reinforcement arrangement, PMM interaction surface was calculated using ETABS section designer module. Several of the wall sections are unsymmetrical, and result in different P-M interaction curves in opposite directions.

For these unsymmetrical wall sections, the appropriate P-M interaction curve corresponding to the direction of pushover was used in defining hinge property.

\subsubsection{Moment-plastic rotation (M- $\theta p)$ relation:}

$M$ - $\theta p$ relation for a shear wall section consists of plastic rotation and corresponding moments as ratio of yield moment. This relation affects the behavior of a section once a hinge forms there. All values needed to define $M$ - $\theta p$ relation may be obtained by following FEMA or ATC guidelines. In this work, values for $\theta p$ were calculated based on the FEMA guidelines and corresponding $M$ values were read from the moment-curvature curves of wall sections, under design gravity load. Moment-curvature curves of wall sections were obtained from ETABS section designer module, which uses stress-strain curve for concrete as suggested by Kent and Park (Park [15]). Plastic hinge length required for this calculation was based on FEMA guidelines.

\subsubsection{Shear wall shear hinge}

Shear hinge property was entirely defined by nominal shear strength without any reduction factor. This was calculated per 1997 UBC. Shear hinges in all elements were considered force-controlled with no ductility and development of any shear hinge was considered undesirable for the design objective.

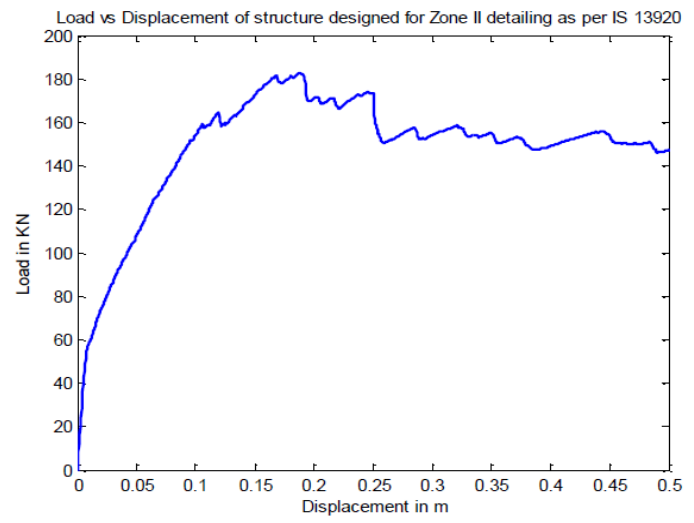

Figure 22: Pushover or capacity curve of structure considered with shear wall

\section{Results and Conclusions}

By the present study, it is concluded that, performance evaluation of RC buildings can be done by using nonlinear static pushover technique. Observing the pushover curves comparison, it can be stated that effect of shear wall in building has significant effect on capacity.

At the left bottom of squat shear wall, more tensile and shear force develops due to lateral forces, so to avoid cracking and failure of shear wall, confinement of reinforcement is done. It increases the load carrying capacity of the building.

Ductile detailing of members does not increase the capacity much, but it increases the ductility significantly.

By using performance evaluation methods, it has been determined that the structures performance will be at Immediate Occupancy (IO) state for the considered demand. Pushover analysis is a useful tool of Performance Based Seismic Engineering to study post-yield behavior of a structure. It is more complex than traditional linear analysis, but it requires less effort and deals with much less amount of data than a nonlinear response history analysis. Pushover analysis was performed on a six story concrete building with shear wall lateral system and certain unique design features. Utilizing the results from this analysis, some modifications were made to the original code-based design so that the 


\section{International Journal of Science and Research (IJSR) \\ ISSN (Online): 2319-7064 \\ Index Copernicus Value (2013): 6.14 | Impact Factor (2015): 6.391}

design objective of Life Safety performance is expected to be achieved under design earthquake.

\section{References}

[1] Applied Technology Council, (1996). "Recommended methodology for seismic evaluation and retrofitting of buildings." Report No. ATC-40, Redwood City, California.

[2] A.K Jain., "Limit State Design of Reinforced concrete structures", NewChand Publishers, Roorkee.

[3] Chopra, A.K. (2007), "Dynamics of structures: Theory and application to earthquake engineering", 2nd edition, Prentice Hall of India.

[4] C.V.R. Murty, "Seismic strengthening of RC framed buildings: A formal Quantitative approach". Journal of Structural Engineering, Vol.35, No.2 (June-July 2008)

[5] "Evaluation of pushover analysis procedures for frame structures" a thesis from Middle East technical University by Sermin Oğuz (2005).

[6] Federal Emergency Management Agency - FEMA 356 "Pre standard and Commentary for Seismic Rehabilitation of Buildings", Department of Homeland Security Federal Emergency Management Agency, Washington, 2000.

[7] Kent, D.C., and Park, R. (1971). "Flexural members with confined concrete." Journal of the Structural Division, Proc. of the American Society of Civil Engineers, 97(ST7), 1969-1990.

[8] Park, R., and Paulay, T. (1971). Reinforced Concrete Structures, 1st Ed., John Wiley \& Sons, Inc, New York.

[9] Paulay and Priestley, "Seismic design of reinforced concrete structures" Copy right(c) 1992 by John Wiley and Sons.

[10] Pushover experiment and analysis of a full scale nonseismically detailed RC structure, Engineering structures, Vol.46, Jan-13.

[11] Neethu K. N, Saji, K.P.'Push over Analysis of RC Buidling." IJSR, Vol. 4 Issue 8, August 2015.

[12] Akanshu Sharma, G. R. Reddy, K. K. Vaze, R. Eligehausen, "Pushover Experiment and Analysis of a Full Scale Non-seismically Detailed RC Structures", Engineering Structures, Vol- 46, pp.218-233, 2014.

[13] IS 456: 2000, "Plain and Reinforced Concrete - Indian Standard Code of Practice", Bureau of Indian Standards, New Delhi, India.

[14]IS 13920: 1993, "Ductile Detailing of Reinforced Concrete Structures Subjected to Seismic Forces- Indian Standard Code of Practice", Bureau of Indian Standards, New Delhi, India.

[15] Bureau of Indian Standards. (2002). "Criteria for Earthquake Resistant Design of Structures." IS 1893 (Part I):2002, New Delhi.

[16] SAP User Manual, version 15, Berkeley (CA, USA): Computer and Structures, Inc., 2000.

\section{Author Profile}

J.Muralidhara Rao received B.Tech. degree in Civil Engineering from Jawaharlal Nehru Technology University, Anantapur, Andhra Pradesh. Presently pursing M.Tech. (Structural Engineering ) in
Siddartha Educational Academy Group of Institutions/Integrated Campus, Tirupati., Andhra Pradesh.

Dr. K. Rajasekhar received B.Tech. in Civil Engineering, M.Tech. in Structural Engineering and Ph.D in Civil Engineering from S.V.University, Tirupati and having more than 25 years teaching experience. Presently working as Professor in Civil Engineering in Siddartha Educational Academy Group of Instututions/Integrated Campus, Tirupati., Andhra Pradesh. 